\title{
THE INFLUENCE OF EDITH STEIN ON INGARDEN'S CONCEPT OF PERSON AND SOUL (CONTROVERSY OVER THE EXISTENCE OF THE WORLD, §78)
}

\author{
SIMONA BERTOLINI \\ $\mathrm{PhD}$ in Philosophy, Scientific Collaborator. \\ Unity of Philosophy, University of Parma. \\ 43125 Parma, Italy. \\ E-mail: bertolini1980@gmail.com
}

As is well known, Roman Ingarden and Edith Stein had a deep intellectual relationship and friendship, which began during their stay in Göttingen and Freiburg. The time spent together during this period and the correspondence that they maintained over the following years allowed them to be in close contact with their respective philosophies and to influence each other. This article aims at illustrating the affinities between Ingarden's description of soul in $\$ 78$ of Controversy over the Existence of the World and the analysis of soul and psyche developed by Stein between 1916 and 1922. Furthermore, it aims at presenting the hypothesis that this analysis influenced the formal anthropology elaborated by the Polish philosopher many years later. Both the depiction of the soul as a personal nucleus that manifests itself in human lived experiences and the description of this manifestation through the notion of "force" are theoretical elements that are essential in Ingarden's mature ontology of man and that already played a crucial role in Stein's early writings. Both thinkers, within several years of one another, elaborated an anthropological view that does not have the life of consciousness as a primary guideline, but that brings to light the ontological relevance of the unitary psychic source of human dispositions, of human character, and of consciousness itself.

Key words: Roman Ingarden, Edith Stein, person, soul, consciousness, psyche, human spirituality, phenomenological anthropology, ontology.

(C) SIMONA BERTOLINI, 2020 


\section{ВЛИЯНИЕ ЭДИТ ШТАЙН \\ НА КОНЦЕПЦИЮ ЛИЧНОСТИ И ДУШИ ИНГАРДЕНА \\ (СПОР О СУЩЕСТВОВАНИИ МИРА, §78)}

\section{СИМОНА БЕРТОЛИНИ}

Доктор философии, научный сотрудник.

Центр философии, Пармский университет.

43125 Парма, Италия

E-mail: bertolini1980@gmail.com

Как известно, во время пребывания в Гёттингене и Фрайбурге между Романом Ингарденом и Эдит Штайн началась крепкая дружба и интеллектуальное соратничество. Совместно проведённое в тот период время, как и переписка, которую они поддерживали на протяжении последующих лет, позволили им ближе ознакомиться с философскими воззрениями друг друга, а также испытать взаимное влияние. Цель настоящей статьи - показать сходство между тем описанием души, которое предлагает Ингарден в $\$ 78$ «Спора о существовании мира», и анализом души и psyche, развитым Эдит Штайн в период между 1916 и 1922 гг. Кроме того, в статье будет выдвинута гипотеза о том, что этот анализ повлиял на формальную антропологию, разработанную польским философом много лет спустя. Как рассмотрение души в качестве личностного ядра, которое проявляет себя в пережитом человеком опыте, так и его описание через понятие «силы», являются основными теоретическими элементами в зрелой онтологии человека для Ингардена, и уже сыгравшими решающую роль в ранних работах Штайн. С разницей в несколько лет оба мыслителя разработали антропологический взгляд, который отказывается от жизни сознания как основного ориентира, но выявляет онтологическую значимость единого психического источника предрасположенностей человека, человеческого характера и самого сознания.

Ключевые слова: Роман Ингарден - Эдит Штайн, личность, душа, сознание, psyche, духовность человека, феноменологическая антропология, онтология.

\section{INTRODUCTION: \\ THE ROLE OF THE SOUL IN INGARDEN'S ONTOLOGY AND STEIN'S EARLY WRITINGS}

As Ingarden declares in his Memories of Edmund Husserl, he first proposed the "essence of the person" as subject of his dissertation with Husserl (Ingarden, 1968, 115-116) ${ }^{1}$. This demonstrates that the Polish thinker's interest in the concept of person has deep roots and dates back to his first years of study in Göttingen and Freiburg,

1 As is well known, Ingarden's dissertation actually focused on Henri Bergson's philosophy (Ingarden, 1994). As we read in Memories of Edmund Husserl, Husserl told Ingarden that dealing with the notion of person would have taken five years, a period of time that Ingarden could not afford (Ingarden, 1968, 116). 
probably under the influence of Max Scheler's Formalism. Although Ingarden did not focus his main efforts on the investigation of this concept after returning to Poland (1918), the role of the notion of person in the development of his philosophy is not irrelevant, as Chapter XVI of Controversy over the Existence of the World (in particular $\$ 78)^{2}$ and the treatise On Responsibility ${ }^{3}$ show. While referring to different theoretical questions (respectively, the realism-idealism debate and the foundations of human responsibility), these writings also deal with anthropological issues and present a clear definition of the human being as a person, on the basis of conceptual cornerstones that Ingarden seems to take for granted and does not question.

Among these cornerstones, the central role of the soul (Seele) within the structure of the person is particularly significant ${ }^{4}$, as is the depiction of the soul as the primal and ineffable nucleus of human personality, which manifests itself in psychic phenomena and does not allow itself to be reduced to conscious, lived experiences. In this regard, Ingarden claims that the positivistic "psychology without soul," which rejects any psychological entity beyond experience (lest philosophy degenerates into metaphysics), soon reveals its poverty because it cannot account for the point of reference of subjective dispositions and capacities, i.e., it cannot answer the unavoidable question "Who is the subject of such dispositions?" . It is therefore the "power of facts" and the rigorous description of human phenomena that make the use of the term "soul" necessary, though released from metaphysical and religious implications (Ingarden, 1965/2016, 306-307/685-686).

In chapter XVI of Ingarden's magnum opus, a crucial question concerns the existential relation between soul and consciousness, with the aim of pondering the methodological assumptions of Husserl's transcendental-constitutive analysis of the person $^{6}$. Could the pure ego and the corresponding stream of consciousness exist

2 When citing quotations from this work, I will indicate both the pages of the German edition and the pages of the English translation. Chapter XVI is entitled The Problem of the Form of Pure Consciousness, whereas the title of $\$ 78$ is The Formal Problem of the Existential Self-Sufficiency of the Stream of Consciousness.

3 The treatise is based on a paper read in Vienna in 1968. See Ingarden (1970).

4 The second part of $\$ 78$ deals with The Stream of Consciousness and the So-called "Soul" (the "Person"). See (Ingarden, 1965/2016, 305/684 ff.).

5 As Gerda Walther recalls, also Alexander Pfänder countered the notion of soul, intended as the result of a rigorous and faithful observation of man, with the positivistic "psychology without soul" (Walther, 1960, 188). Pfänder exposed these observations in the work Die Seele des Menschen (Pfänder, 1933).

6 In this respect, the main point of reference is the second volume of Ideas, published in 1953 and explicitly mentioned by Ingarden in the German edition of Controversy (Ingarden, 1965/2016, 
without being rooted in the person's soul? Are they ontologically "self-sufficient" (seinsselbständig) and "independent" (seinsunabhängig) in relation to it ${ }^{7}$ ? Or-on the contrary-can they exist only as an "axis" and a manifestation of the soul's individuality (Ingarden, 1965/2016, 319/696)? These questions, which belong to the wider question about the relation between consciousness and the real world, do not aim at confuting Husserl's transcendental idealism from a metaphysical viewpoint, but intend to sift through its presuppositions by investigating the objective kinds of dependence that emerge from the description of the ideas of soul, consciousness, and person ${ }^{8}$. If this description proves-as actually happens to be the case-that the existence of consciousness, according to its eidetic structure, depends on the identity of the soul and not conversely, the absolute way of existence of the pure ego would be contradicted. Accordingly, Husserl's philosophical approach, which traces the constitution of man back to the field of pure consciousness, would turn out to be based on existential relationships without foundation?.

This is the problematic context in which the examination of man's personal distinctiveness develops in $\$ 78$ of Controversy, starting from the eidetic observation of human phenomena. This examination brings to the fore that the unity of the soul is the focal point of human character and behavior, as well as the center of a "monad" that includes both the life of consciousness and the body (as is confirmed in the third part of $\$ 78$, dedicated to the existential relation between consciousness, body and soul (Ingarden, 1965/2016, 326/701 ff.)). The same anthropological view is also illustrated in the treatise On Responsibility, wherein Ingarden aims at delineating a structure of the human person able to ground and account for the existence of responsible decisions and deeds. In this writing, as in Controversy, the thinker shows that addressing man as the product of transcendental constitution does not allow to understand hu-

305/684, 315/692). In addition, it is worth recalling that Ingarden personally attended Husserl's Vorlesung on Nature and Spirit in 1913 (Ingarden, 1968, 109).

7 The meaning of these adjectives is presented in the first volume of Controversy and refers to different existential moments, concerning distinct modes of ontological dependence or independence. From this point of view, an entity can be: 1) autonomous or heteronomous, 2) original or derivative, 3) self-sufficient or non-self-sufficient, 4) independent or dependent (Ingarden, 1964, 78-123). In particular, an entity is self-sufficient if its being, according to its essence, does not need the being of other entities within the unity of a whole, whereas it is independent if it does not need the existence of another self-sufficient entity in order to keep on existing.

8 Ingarden presents the ontological foundations of eidetic ontology itself in Chapter X of Controversy, titled On the Form of Idea. On this topic, see also Ingarden's Habilitationsschrift (Ingarden, 1925).

9 In this regard, Ingarden claims that Husserl confused the way of givenness (Gegebenheitsweise) with the way of being (Seinsweise): see (Ingarden, 1965/2016, 323/698, 371/739). 
man complexity, for the stream of consciousness is just one part of the wider structure of real man. The latter is defined by Ingarden as "a corporeal-psychic-spiritual being," whose identity, as temporally extended, depends on the manifestation of its soul in temporal conscious life (Ingarden, 1970, 54, 66).

While the concept of the person is a recurring topic in phenomenological tradition, the constitutive relation between person and soul is specifically reminiscent of the anthropological analysis that is at the center of several works by Edith Stein. In Stein's works the notion of soul plays a crucial role (Ales Bello, 2001; Calcagno, 2019; Knaup \& Seubert, 2017, 334-338). In particular, Ingarden's depiction of this notion is reminiscent both of the concept of soul that appears in the third part of Stein's dissertation on empathy (defended in 1916 in Freiburg and partially published in 1917 (Stein, 2010b)) and of the definition of the psyche provided in other texts, which she wrote in the next few years, such as Introduction to Philosophy (Stein, 2004) ${ }^{10}$ and the two treatises gathered under the title Contributions to a Philosophical Foundation of Psychology and the Humanities (Stein, 2010a) ${ }^{11}$. In contrast to other following works, in which Stein interprets the results of the phenomenological analysis of man in light of Scholastic tradition conceptuality (see, for instance, Stein, 2005), ${ }^{12}$ here she develops a rigorous description of human psychic life by employing categories that will be present in Ingarden's Controversy as well.

The aim of the following sections is to illustrate these similarities between Ingarden's description of soul and Stein's early writings (Sections 2 and 3), and to present the hypothesis that some of these writings influenced the anthropology elaborated by the Polish philosopher many years later (Section 4). After all, he was in Freiburg with Stein when she defended her dissertation, and the letters she wrote to him from 1917 to 1938 prove the existence of a close intellectual relationship between the two thinkers (Stein, 2015). Hence it is plausible to assume that Ingarden, through the me-

10 Introduction to Philosophy was initially a manuscript, published posthumously in 1991 . The writing of the text went through many phases (Stein, 2004, XX ff.), but the whole structure of the work was already finished in 1921, as the editor of the corresponding volume in the Edith Stein Gesamtausgabe confirms (Stein, 2004, XXVI).

11 The text was published in 1922 in the fifth volume of Husserl's „Jahrbuch für Philosophie und phänomenologische Forschung." It consists of two treatises: Psychic Causality and Individual and Community. The title of the published English translation of the work is Philosophy of Psychology and the Humanities (Stein, 2000).

12 Stein's project of connecting Husserl's phenomenology and Thomas Aquinas' metaphysics began between 1925 and 1929. An important milestone was the writing Husserl's Phenomenology and the Philosophy of St. Thomas Aquinas (1929) (Stein, 2014, 119-142). 
diation of his friend's early works, elaborated an anthropological paradigm and a view of psychic phenomena that would play a central role in his mature ontology.

Although the reflections which Stein developed after her dissertation silently look to a metaphysical meaning of the term "soul" (as I will show in Section 3), they also bring to the fore a structure of the psychic individual that turns out to be well-suited for explaining the evidence of the human phenomenon. This structure, which was already mentioned in her writing on empathy, makes it possible to ontologically combine the identity of the human person and its manifestation through personal qualities and through the flux of lived experiences, thereby structurally justifying both the person's dynamic expression and the person's unity. It is probably this combination, faithful to the "things themselves," that led Ingarden to include, in his systematic ontology, some theses presented by his friend many years before.

Besides the intentional openness to values, to cultural objects, and to other persons ${ }^{13}$, the essence of the person also implies a sort of unitary, pre-conscious and non-transparent origin, which reveals itself in human acts and experiences, thus ensuring that such experiences leave the mark of one's own character and belong to the continuity of one's own personal story. On the one hand, the admission of this origin echoes the relationship between background and surface that was presupposed in pre-Cartesian interpretations of the notion of soul, which theorized the existence of a substantial entity at the basis of human spiritual activities. On the other hand, this admission can go hand in hand with a faithful and non-dogmatic description of the human being, which focuses on its specific structure. As we will see, this phenomenological aim orients both Ingarden's mature ontology of man and Stein's early analysis of the human soul and psychic life.

\section{RELATION AND DIFFERENCE BETWEEN SOUL AND CONSCIOUSNESS IN \$78 OF "CONTROVERSY OVER THE EXISTENCE OF THE WORLD”}

Stein, in the third part of her writing on empathy, defines the soul concisely and describes its relation to-and difference from-the pure ego:

Our uniformly isolated stream of consciousness is not our soul. But, as we already saw in examining inner perception, among our experiences there is one basic experience given to us which, together with its persistent attributes, becomes apparent in our experiences as the identical "conveyer" of them. This is the substantial soul. [...]. The acuteness of

13 The centrality of these topics has been highlighted by several phenomenologists, such as Scheler, Hartmann, and Husserl himself. See (Hartmann, 1926; Husserl, 1952; Scheler, 1980). 
our senses apparent in our outer perceptions is such an attribute. Another is the energy apparent in our conduct. The tension or laxity of our volitions manifests the vivacity and strength or the weakness of our will. (Stein, 2010b, 55-56)

This substantial unity is "my" soul when the experiences in which it is apparent are "my" experiences or acts in which my pure "ego" lives. The peculiar structure of psychic unity depends on the peculiar content of the stream of experience; and, conversely, [...] the content of the stream of experience depends on the structure of the soul. (Stein, 2010b, 56)

It is worth pointing out at least three essential elements in these quotations. Firstly, the soul differs from the stream of consciousness and is conceived as an identical and substantial "conveyer" of conscious experiences, which conditions them. Secondly, the unity and uniqueness of the soul lies at the basis of the inner coherence of the pure ego, i.e., of human subject's life of consciousness. Further, from a methodological viewpoint, Stein specifies that this definition of the soul "becomes apparent in our experiences," consistently with the assumptions of the phenomenological method. Although the thinker mentions Husserl's Ideas in her dissertation (Stein, 2010 b 6), a realistic and not transcendental approach towards the object is evident, in line with the realistic phenomenology of the so-called "Göttingen Circle" (Avé-Lallemant, 1975a, 1975b), of which Stein and Ingarden were active members before moving to Freiburg to follow their master.

The same theoretical elements also play a central role in $₫ 78$ of Controversy over the Existence of the World, wherein Ingarden distinguishes between stream of experience and soul, regarding the latter as the core of the person's uniqueness ${ }^{14}$, and claiming that the pure ego is "grown into" it (hineingewachsen) (Ingarden, 1965/2016, 320/696). Moreover, the Polish thinker likewise argues that the admission of a close relation between lived experiences and their unitary foundation is evidence given to us, based on an original and concrete experience of ourselves (Ingarden, 1965/2016, 320/696). This experience reveals that the unity of personality is not the constitutive result, but rather the source of the stream of consciousness, which manifests itself in it, thus guaranteeing its inner coherence and personal "tone." Therefore Ingarden, as Stein, seems to circumscribe a notion of soul that presupposes a peculiar path of analysis, which implies the observation of man and consciousness in light of phenomenological reduction, and results in implicitly and ontologically denying the assumptions of Husserl's transcendental phenomenology. In fact, the pure ego finally turns out to

14 The terms "soul" and "person" are mentioned as synonyms (Ingarden, 1965/2016, 305/685, 307/686, 320/696). 
be founded in yet another source. Instead of being regarded as the field of constitution, it is traced back to the ontological primacy of the soul.

Ingarden describes the soul as the "nucleus" (Kern) and the primal psychic entity in which personal dispositions (Dispositionen), capacities (Fähigkeiten), and forces (Kräfte) are anchored (Ingarden, 1965/2016, 308/687, 314/691) ${ }^{15}$, even though its definition cannot be referred to their totality and sum. If compared to the abilities and lived experiences that arise from its primacy, the soul appears to be the secret origin of every man's singular nature and "haecceitas" (Ingarden, 1965/2016, 315/692), which never reveals its properties as a whole, showing itself fragmentarily and through the single traits of the individual's character and behavior; as Ingarden claims, "this nature is precisely something that is alien to me, almost incapable of being grasped in its primacy and uniqueness" (Ingarden, 1965/2016, 315/692). Because of this intangibility, we usually capture the soul's properties "linguistically under the aspect of the ego's modes of conduct or experiences, instead of grasping them directly in their distinctiveness" (Ingarden, 1965/2016, 316/692-693). Thus, adjectives such as serious, intelligent, bad, etc., when referred to a person, are not usually regarded as indications of the soul's properties from which the corresponding behaviors and experiences originate, but they are assumed to indicate such behaviors and experiences. According to Ingarden, this is a "behavioristic" way of understanding that restricts itself to dealing with human expressions and neglects the determining role of both individual personality and character traits (Ingarden, 1965/2016, 316/693). As the philosopher specifies, this hurried interpretation of phenomena, which focuses on what is founded and forgets the evidence of its foundations, "is precisely what provided the impetus for the positivist critique [...] -according to which the steadfast traits of the human or personal psyche are to be regarded as conceptual hypostases to which nothing corresponds in reality" (Ingarden, 1965/2016, 317/693). In saying this, positivist philosophy misses the chance of comprehending the constitutive nature of human individuals, on which their distinctiveness depends.

It can be said that Stein's expression "substantial soul" may be employed with reference to Ingarden as well, provided that the term "substantial" is intended in a formal and non-metaphysical sense, that is, with reference to the focal point of the structure of the human person, according to its eidetic evidence. Just as Stein affirms that the substantial unity of the soul is "apparent" in the acts of the pure ego, Ingarden maintains that the pure ego, by being founded in the peculiarity of the soul, is the

15 I partially distance myself from the published English translation of the work (Ingarden, 2016), in which the terms „Kern,“ „Kraft,“ and „psychisch“ are translated as “kernel,” "power," and “mental” respectively. 
center (Zentrum) and the axis (Achse) around which the soul's properties are congregated, and from which lived experiences "emanate" (hervorschießen) and unfold in a flux. The fact of having this center, wherein what happens in the soul "becomes wakeful (wach wird) and attains appearance (zur Erscheinung gelangt)," characterizes the peculiar structure of the human soul (Ingarden, 1965/2016, 320/696). A constitutive and inseparable relation between soul and consciousness thus emerges from Ingarden's work, insofar as the former would be just a potential origin of forces and capacities without the latter, whereas the latter, without the former, would be just a "naked skeleton" (Ingarden, 1965/2016, 321/697). Almost echoing the last words of Stein we have cited, Ingarden theorizes the existence of a symmetrical correspondence between the content of the stream of consciousness and the richness of the soul (Ingarden, 1965/2016, 324/699-700), which entails that analyzing them as if they were separated is just an abstraction that has to be overcome in order to recompose the complex articulation of human reality.

While an ego without a soul would be a naked and cold "skeleton," a soul without ego would lack the "dominant, ordering or organizing" factor that allows it to become a person (Ingarden, 1965/2016, 321/697). Being a person, in fact, requires having a soul and revealing its properties both to the external world and to the personal self-consciousness. Otherwise put, it is the emerging of the conscious identity of the ego, rooted in the unity of the soul, that ensures the organization and "liberation" of the personal potentialities of human essence, which implies the presence of conscious acts, conscious deeds, intentions, responsibility, and ethical life. Hence, the ego is not only the condition for the possibility of man's expression and knowledge, but is the conditio sine qua non of the human person's whole and very own essence (Ingarden, 1965/2016, 322/697).

Ingarden also outlines this very same complex of conditionings in the treatise On Responsibility, which aims at illustrating a structure of man and world that is compatible with human responsibility and freedom ${ }^{16}$. With reference to this structure, he defines the soul as a "relatively isolated system" 17 that is partially open and partially closed in its relation to the stream of consciousness: open because it expresses itself in and has effects on conscious life, closed insofar as man cannot become aware of the whole deepness of his soul (Ingarden, 1970, 93-94). Also in this writing, the ego is depicted as "the organizational center of the human soul, which embodies and represents it," and which speaks on behalf of it, by performing acts, assuming responsibili-

16 On this topic, see (Bertolini, 2019).

17 The concept of relatively isolated system is a formal concept that plays a crucial role both in this treatise and in the last volume of Controversy (Ingarden, 1974). See also (Makota, 1990). 
ties, entering into obligations, etc. (Ingarden, 1970, 92-93). Simultaneously, as for the concept of soul, Ingarden reiterates and confirms the theses exposed in his magnum opus, by asserting that the soul "is in itself not experience, but it expresses itself in experiences," thereby being the origin of both human thought and volitional decisions (Ingarden, 1970, 92). As is evident, the concept of a relatively isolated system does not serve to provide a radically new perspective in this treatise, but supplies a structural law that allows Ingarden to differently present and to complete the anthropological balance described in Controversy, to the extent that it formally justifies how different human elements, such as soul and consciousness, refer to each other and maintain their peculiarity at the same time.

The concept of a relatively isolated system and the notion of soul also provide the formal foundations of some reflections on the essence of man developed by Ingarden in other writings, which were published in 1983 in the volume titled Man and Value: Man and His Reality (1935), Man and Nature (1958), and On Human Nature (1961) (see Ingarden, 1983, 17 ff.). In these essays, the thinker depicts man as a peculiar being which lives on the substratum of nature and exists "on the boundary of two different essences," namely on the boundary between an animal essence and a human essence (Ingarden, 1983, 20). On the one hand, human beings differ from animals due to their spiritual life and to the actualization of this spirituality within a cultural and moral world. Unlike animals, man can transcend his immediate experience and actualize values such as goodness, beauty, truth, and justice (Ingarden, 1983, 29) ${ }^{18}$; this is valid both for human individuals and for the cultural context by which individuals are conditioned. On the other hand, these specifically human qualities and the human world constitute a "superimposed reality" that emerges from, depends on, and perpetually attempts to go beyond the natural world (Ingarden, 1983, 29): "such is the tragedy of man's fate" (Ingarden, 1983, 20). In this regard, the notion of soul can be considered as the pivot of the psychic structure that underlies these higher and spiritual potentialities of the human person, and that makes it possible, from a formal point of view, to overcome a merely biological and animal way of living in the world.

Let us return now to Chapter XVI of Controversy. By investigating in a more detailed way the psychic capacities that are "anchored" in the soul and constitute the concreteness of the person, Ingarden speaks of psychic forces that are "actively present and exert an effect" (Ingarden, 1965/2016, 309/687), thereby insisting on their actuality and reality. This means that the capacities and dispositions that the individual feels

18 Ingarden focuses on the notion of value in other essays published in the same volume: see (Ingarden, 1983, 119 ff.). 
in itself are not "illusions," i.e., the final result of the temporal flux of lived experiences, but imply real and effective forces and psychic entities that manifest themselves in personal life. Consequently, calling these capacities by a specific name does not simply represent a useful_but misleading — stratagem able to linguistically communicate the experience of human interiority, but objectively refers to actual elements of psychic reality. The ontological identity of this reality has to be admitted in order to faithfully conceptualize what emerges from our experience. To give an example, when we feel we have the ability to solve a problem, it is the concrete power of our capabilities that we find in ourselves. Instead, when we fail to do something (for instance to remember a name or an important fact), "we knock [...] at the door of our selves, but there is no one to answer us" (Ingarden, 1965/2016, 309/688, 311/689).

Besides the force of understanding and apprehending, Ingarden also mentions artistic competences among human psychic forces, such as the dexterity that the highly-skilled musician feels when performing a symphony with naturalness. This naturalness does not come directly from the mechanical acquisition of a good technique, but rather from the inexplicable energy thanks to which this technique can be transformed into a unitary and moving performance:

We sense that we can achieve certain accents, effects, mood characteristics, in which the whole excellence of the work becomes manifest, but in which also our whole power-the intensity of our feeling, the swing of fervor and submission, the power, finally, of our secure mastery of all the reproductive and creative means that are available to us-attains intuitive expression. We are not at all reflectively oriented towards this, as if we meant to unveil all of this in the interest of theory. On the contrary, we experience it so-to-speak altogether involuntarily. (Ingarden, 1965/2016, 311/689)

Just as we feel the influence of our psychic reality when we find the key to solve a difficult problem, we likewise feel the presence of an almost uncontrolled force when the results of our exercise in a specific field take a spontaneous, holistic, and autonomous shape. Moreover-Ingarden adds-this psychic dynamic shows itself in human practical and moral life, coinciding with the interior vitality that urges us to overcome obstacles or even dangers when we defend our love for a person, when we uphold an ethical ideal, etc. (Ingarden, 1965/2016, 312-313/690). It is this actual and effective presence within us that gives us the courage to fight for what we believe in and to resist, "though it would have been easier to capitulate" (Ingarden, 1965/2016, 313/690).

As is evident, the formal hypostatization of the soul allows Ingarden to circumscribe the ontological identity of the diverse elements constituting the individual psyche: intellectual and moral predispositions, abilities, force of character, as well as the inner force and the qualitative tone that silently condition the way in which hu- 
mans experience the world. Instead of interpreting such elements in light of Husserl's notion of constitution, the thinker regards them as potentialities that lie within and arise from the unitary source of our soul, which is the reason why every single one of us can refer to them by using the possessive adjective "my" (Ingarden, 1965/2016, $314 / 691$ ). Hence, conscious lived experiences are not the constitutive origin, but rather the manifestation of these psychic personal traits, without which both the deepness and the inner consistency of the ego would be unfounded. For Ingarden, the pivotal role both of the soul's nucleus and of the psychic complexity anchored in it is one of the most unequivocal results of the pure description of the "thing itself" with reference to the human being.

\section{AFFINITIES BETWEEN INGARDEN AND STEIN: PSYCHE, CHARACTER, AND PSYCHIC FORCES}

The affinity between Ingarden and Stein mentioned in the previous section goes beyond the brief definition of soul provided in the treatise On the Problem of Empathy. Rather, this affinity is confirmed by other works of Stein, which were written in the immediately following years. By describing the human phenomenon in several respects, Stein also draws attention to the ontological unity that characterizes the psychic structure of the person, while depicting this structure as the real basis of the life of consciousness. For Stein, as for Ingarden, the observation of human reality reveals a nucleus of identity that phenomenological research has to conceptualize as nucleus, without tracing it back to the constitutive becoming of lived experiences. By contrast, ignoring the evidence of this substantial structure of man would amount to neglecting the first aim of phenomenology, that is, the aim to describe reality as it manifests itself in our experience.

A terminological specification is needed before considering Stein's claims. If we compare On the Problem of Empathy with other works of the following years, two different meanings of the term "soul" become apparent: whereas Stein, in her dissertation, defines the soul as a psychic center of phenomenal possibilities, she subsequently refers to the same center while using the term "psyche" and employs the word "soul" with a different meaning, influenced by Hedwig Conrad-Martius' Metaphysical Dialogues (Conrad-Martius, 1921) ${ }^{19}$. According to this meaning, the concept of soul

19 Stein expressly mentions Conrad-Martius' work as a theoretical point of reference (Stein, 2010a, 191). On the relationship between the two thinkers, see (Ales Bello, 1993; Avé-Lallemant, 2003). As we read in a letter, Ingarden considered Conrad-Martius' Dialogues as a "poetic fabrication" (Stein, 2015, letter 80, December 13, 1921). 
seems to lose its purely psychic and descriptive implications (as source of all the qualities that actually characterize a person) and presents itself as a prescriptive notion, concerning the integrity that ought to guide the psychophysical unity of every person, in line with its interior purity. To give an example, Stein provides a moral definition of the term in Individual and Community (the second treatise of Contributions to a Philosophical Foundation of Psychology and the Humanities), wherein the soul's properties do not overlap with the whole set of the psyche's dispositions ${ }^{20}$. Rather, they exclusively coincide with those properties of character that enable the sensitivity to moral values, such as "purity, goodness, nobility" (Stein, 2010a, 193). By defining the soul as nucleus, root, and center of the person (Stein, 2010a, 191), the thinker links such terms to moral potentialities, whereas the psyche-and not the soul-is here depicted as the "substantial unity of the whole sensible-psychic-spiritual being and life of individuals" (Stein, 2010a, 199). In this regard, she claims that a psyche "without soul" is possible (Stein, 2010a, 192) 21.

It is undeniable that in 1922, in spite of the rigorously descriptive approach of both treatises published in Husserl's Jahrbuch, a metaphysical interpretation of the notion of soul replaced the meaning sketched a few years before in Stein's dissertation-the same metaphysical interpretation that would play a primary role in her future thought. After all, in Introduction to Philosophy Stein specifies that, for her, the meaning of "soul" is closer to a religious-metaphysical one (Stein, 2004, 145). Further she confirms that she speaks of "psyche" and "soul" while alluding to different entities (Stein, 2004, 124) 22: the former is the "unity of all internal qualities and states of a real subject" (Stein, 2004, 144), whereas the latter is the profound origin of human personality and the internal "place" in which every person receives the world of values in itself (Stein, 2004, 136-137).

According to these assumptions, it is in Stein's observations on the human psyche that the main structural affinities with Ingarden's conception of soul can be found. In this respect, the section of Introduction to Philosophy dedicated to The Structure of

20 "Unlike psyche, this being of soul is not a set of permanent properties" (Stein, 2010a, 192-193).

21 In this respect, in the treatise Freedom and Grace (1921) Stein distinguishes between the soul's natural-naive life and the soul's liberated life. The former consists in a constant interplay between impressions and reactions, which implies that the subject is not free and that its actions are not rooted in a subjective center; this passive activity, Stein specifies, characterizes the animal level of life. In contrast, the latter is a kind of life that is not urged "from the exterior," but "from above" and "from inside." In this case the subject is not immediately conditioned by the external impressions, but receives them from its center (see Stein, 2014, 10-12).

22 While reworking the text of Introduction to Philosophy, Stein replaced the word "Seele“ with the term „Psyche“ sixty-five times (Stein, 2004, XXXI). 
the Psyche provides significant indications (see Stein, 2004, 123, ff.). First of all, at the beginning of this section Stein stresses the difference between psyche and consciousness, insofar as consciousness (understood as pure consciousness) is set against that which exists, whereas psyche is a transcendent entity belonging to the existing real world, i.e., a unitary "substance" the "accidents" of which are conditioned by external circumstances and change over the course of time (Stein, 2004, 124). Stein's explanation of the relation between psyche and consciousness reminds us of the relation between consciousness and soul delineated both in On the Problem of Empathy and in Ingarden's Controversy:

Then, the states of the psyche are not only real psychic states, but also lived states of the ego, to which this psyche belongs; and the lived experiences through which they manifest themselves can also be considered as pure lived experiences, without taking into account what they are in the context of the real world. Here we can see the relation between psyche and consciousness. The totality of lived experiences of a person, in which its psychic life manifests itself as conscious life, amounts to the flow of consciousness of this person. At the same time, the psychic states are real states, conditioned by reality and with real consequences. (Stein, 2004, 125)

Both consciousness and the possibility to observe its pure lived experiences are mentioned in the context of a wider ontology of man, in which the substantial core of the person conditions the temporal development of conscious life. Consciousness is the field of manifestation of a real subject having specific real qualities, which depend on it and contribute to constituting its unity at the same time.

Stein defines these qualities as "dispositional" and claims that they "coincide with capacities in relation to certain states." Additionally, she distinguishes between two kinds of dispositions, the order of which overlaps with that of lived experiences (Stein, 2004, 126): sensitive dispositions, such as the acuteness of eyesight and hearing, differ from spiritual faculties, which include intelligence, willpower, passionate nature, etc. All these psychic qualities take shape through the sequence of psychic states and by means of the influence of the external world, on the basis of an initial predisposition: "what is not predisposed in the psyche cannot develop in any way" (Stein, 2004, 127). According to their substantial nature, psychic subjects contain a core that cannot change and this restricts the possibilities of individual development.

Like Ingarden, also Stein places emphasis on the relationship between this core and the character of the person, which is conditioned by, but does not coincide with the totality of the psyche. As we read in Introduction to Philosophy, neither sensitive dispositions nor intellectual faculties are part of the character's qualities. It is true that "the fact of being an intelligent or a stupid person" conditions the formation of the 
person's character, but it does not belong to its being, insofar as "the authentic domain of character is the sphere of temper and will": "character is the capacity to feel and the force through which this feeling can turn into will and action." Furthermore, since human feeling always entails the feeling of values, character also implies a certain openness to values and the specific way in which man acts to realize them (Stein, 2004, 128).

Although a character can be understood in light of a model, it has an individual tone that represents the most significant mark of human personality, distinguishing one person from all others. This tone, this individual quality, concerns the experience of values but can also condition our intellectual life, such as when we face a problem in a specific way (Stein, 2004, 133); whereas our intellectual predispositions can be identical to those of other individuals, the way in which we feel and manifest them is unique. Among the predispositions that constitute the complexity of the psyche, the character's inclinations are peculiar insofar as they contain an irreducible qualitative moment, which runs through the totality of the person, ensuring a unitary and distinctive expression. This qualitative moment, for Stein,

is the essence of the person, which does not develop, but unfolds through the development of its character [...]; it is the identical nucleus which is present in all its possible developments and results (conditioned by external relations), while restricting the sphere of these possibilities. (Stein, 2004, 134-135) 23 $^{3}$

Not only does this nucleus condition the fact that a person is receptive to some values, but it also conditions the qualitative tone of this receptivity, such as the personal way of preferring a work of art, of loving someone, etc. (Stein, 2004, 135-136). Put another way, it influences both some dispositions, which a human being may have in common with others, and its inimitable individual traits (its haecceitas, as we have read in Controversy).

These theses, systematically exposed in Introduction to Philosophy, also appear in the two treatises published in 1922. In Individual and Community, in particular, in the section dedicated to Psychic Capacities and the Community's Character, Stein addresses the structure of the psyche and traces psychic capacities back to initial individual dispositions. Furthermore, she highlights the peculiar role of personal character and its relation to values, while defining it as the core of the person (Stein, 2010a, 190). The above mentioned description of the unitary psychic reality is also present in this treatise, although here Stein draws attention to moral traits of character, rooted in the deepness of the soul. In this work, the phrase "nucleus of the person" refers to

23 In this context, Stein mentions both Simmel and Schleiermacher (Stein, 2004, 135, fn. 155). 
character only indirectly, insofar as the authentic nucleus of the individual is the intangible source of morality and sensitivity hidden in the soul's interiority, the purity of which reveals itself in some qualities of character, such as nobility and goodness (Stein, 2010a, 193) ${ }^{24}$. In contrast, negative qualities, such as cruelty and insensitivity to values, have to be interpreted as clues of a superficial psychic development, i.e., of a psychic life that has forgotten the profundity of its nucleus. As already stated, a descriptive approach and a prescriptive perspective intersect in the definition of psyche provided by Stein in this contribution.

Stein also reiterates the distinction between psyche and pure ego in Psychic Causality (the first treatise of Contributions) ${ }^{25}$, as she defines the psychic ego as a transcendent reality that is bearer of its qualities and manifests itself in the contents of lived experiences (Stein, 2010a, 22). Unlike "the psychic" (das Psychische), consciousness is the dimension of pure immanent experience and phenomenal causality, in which "psychic causality" shows itself on the basis of the real individual's persistent qualities (Stein, 2010a, 24). Both the difference and the relation of dependence between the stream of consciousness and the unity of psychic life, which play a central role in the section of Ingarden's Controversy dedicated to the concept of person, are confirmed in this treatise, proving themselves to be a common thread in Stein's reflections of these years.

Further affinity between Stein and Ingarden emerges from Psychic Causality with regards to the concept of force. Stein speaks in fact of "psychic force" and "lifeforce" (Lebenskraft) in Chapter 2. Just like Ingarden several years later, she intends to describe the unitary pole of psychic reality and draws on the notion of "force" in order to explain both its articulation through psychic qualities and the way in which the latter affect conscious life ${ }^{26}$. "Life-force" is the fuel of the development of human psyche, without which human dispositions could not become actual; it is the driving force and the core of what Stein calls "psychic causality." Whereas Ingarden mentions several psychic forces, such as those we have listed in the previous section (artistic force, moral force, etc.), Stein presents the same psychic structure in a different way. Firstly, she distinguishes between life-force (employing the expression in the singular)

24 Stein, after dealing with the concept of character, deepens the concept of soul also in Introduction to Philosophy (see Stein, 2004, $136 \mathrm{ff}$.). She thus admits the relation between the character's nucleus and the soul's nucleus in this work, too.

25 I partially distance myself from the published English translation of the treatise (see Stein, 2000), in which the adjective "psychisch" is translated as "sentient."

26 Stein stresses a certain affinity between her concept of life-force and the concept of psychic force presented by Theodor Lipps in Leitfaden der Psychologie (Stein, 2010a, 22, fn. 30). 
and the diverse capacities that "feed on" it: "There is only one life-force, but there are many capacities" (Stein, 2010a, 165). Secondly, she specifies that life-force is limited, which implies that the development of one capacity necessarily goes to the detriment of others. In so doing, the philosopher offers the conceptual means to differentiate the predispositions of the psyche from the force that allows them to flourish and to become well-formed qualities. As Stein clarifies, life-force is the source of the "tension" (Spannung) and "coloration" (Färbung) of lived experiences, without which the psychic life would not be imaginable (Stein, 2010a, 26).

Besides this main affinity, other analogies between Ingarden and Stein can be highlighted. Firstly, Stein too stresses the reality and actuality of the psychic force, stating that it is "a persistent real property" having a "real state" and an effect in "actual life" (Stein, 2010a, 22, 23, 29). Otherwise put, Stein too connects the ontological identity of the psyche to the reality of the power by means of which it manifests itself. Secondly, both philosophers distinguish between spiritual and non-spiritual manifestations, thus admitting a sort of layering within psychic life. Just as Ingarden alludes to the distinction between spiritual forces and "merely vital" forces (Ingarden, 1965/2016, 313/691), Stein speaks of a sensitive and of a spiritual life-force, holding them to be "different roots of the psyche": while the former coincides with vital states related to conditions of sensitive life (for example, "the freshness and the lassitude that seem to flow through the body and its limbs"), the latter is the strength that allows man to respond vitally to specific contents essential for human life (Stein, 2010a, 70, 72-73). In this respect, the author cites the driving impetus of the feeling of value, which also appears as an example of spiritual force in Ingarden's Controversy:

I acknowledge the value of a work of art but I cannot get excited; I acknowledge the baseness of a feeling but I cannot be indignant; I acknowledge the particular value of a man but I cannot love him. This impossibility to experience contents of considerable importance, rejecting the appeal of the world of values, [...], unveils the spiritual life-force as a driving force that belongs to spiritual dynamics. (Stein, 2010a, 72)

Spiritual force, both for Ingarden and for Stein, is that which urges man to open himself to the world while fully experiencing it, either through the emotional acknowledgment of values or through the emotional way of living persons, things, actions, and situations. It is because of this force that man does not limit himself to being rationally aware of the world, but can feel the world in a personal way, by which human actions are conditioned in turn. In other words, it is because of this force that man has a character and achieves his full humanity, thereby differing from animals and from machines. On the one hand, spiritual actuality depends on sensitive life- 
force, inasmuch as persons, if their body is debilitated, can barely feel enthusiasm. On the other hand, in spite of this dependency, spiritual force is an autonomous source of psychic life, for it "can be capable of achievements that do not correspond to the state of sensitive life-force" (Stein, 2010a, 70-71). As is evident, the cooperation between these different kinds of life-force is the necessary condition for the psychic structure, which is described by Stein in other works, to coincide with the psychic identity of a real living person actually experiencing the real world.

\section{CONCLUSION:}

SOME REFLECTIONS ON THE RELATION BETWEEN INGARDEN AND STEIN

We can confirm that Ingarden's concept of soul, presented in $\$ 78$ of Controversy, presents essential similarities to Stein's description of psychic life. Firstly, both views conceive the life of consciousness as manifestation of a unitary psychic entity, which belongs to the real world and is at the basis both of the person's individual character and of personal specific dispositions. This, compared to the methodological assumptions of Husserl's transcendental phenomenology, entails an essential difference in that the ontological description of reality grounds the possibility of circumscribing the field of pure consciousness, and not conversely. Secondly, the notion of force turns out to be well-suited to describe psyche's effect on human experience, inasmuch as the latter cannot be reduced to knowledge of the surrounding world, but implies that the whole human life has an emotional and vital "coloration" (with Stein's words). This structure of the human being, on which Ingarden focused during his formal analysis, had already found in Stein's early philosophy a rigorous systematization, within the context of a realistic-phenomenological description of man's psychic sphere.

Furthermore, both philosophers, while emphasizing the unity of this sphere, refer to its origin by utilizing similar terminology and conceptuality. They speak in fact of "soul," "nucleus," and "individual essence" of the person, they specify that this nucleus cannot be reduced to the totality of human capacities, and they stress its intangibility. On the one hand, Ingarden does not link the term "soul" to the metaphysical, purely spiritual, and moral meaning referred to by Stein in the writings following her dissertation ${ }^{27}$. As already stated, Ingarden limits his analysis of subjective reality to description and does not conceive of the soul as the interior source of personal integrity. Yet, on the other hand, the fact remains that both thinkers move from the ob-

27 Ingarden was aware of this change in Stein's terminology (see Ingarden, 1999, 252). 
servation of the elements that constitute the person's psychic identity to the question about the center and the origin of such elements, by tracing it back to a substantial and irreducible nucleus that can be indicated but not described.

These affinities allow us to suppose that Ingarden, while expressing his concept of soul in $\$ 78$ of Controversy, was looking to Stein's early analyses as a point of reference and was developing a view elaborated many years before thanks to the dialogue with such analyses. Whereas he could not have read the text of Introduction to Philosophy, he certainly had read both On the Problem of Empathy and Contributions to a Philosophical Foundation of Psychology and the Humanities, as the correspondence between Ingarden and Stein confirms. In this regard, in a letter dated April 27th 1917 Stein alludes to some objections of Ingarden to her dissertation and adds: "I know the concept of the psychic is still not clear" (Stein, 2015, letter 17)—words confirming that Ingarden was interested in her definition of soul and psychic life already in $1917^{28}$. Moreover, Stein's letters show that in 1918 and 1919 she was bringing him up to date with the writing of her treatises Psychic Causality and Individual and Community (Stein, 2015, letters 37, 65), initially earmarked for a Festschrift dedicated to Husserl and only later published in the Jahrbuch. In 1920 she wrote to him: "I am curious to know what you will say about my work that will be published in the Jahrbuch. Will you like it more than the dissertation?" (Stein, 2015, letter 71). Ingarden certainly read the two treatises, also considering that the text of his dissertation was published in the same volume. It is therefore not surprising that Stein, in a 1930 letter, while suggesting some revisions of the manuscript of The Literary Work of Art, claimed to have found in the text an implicit reference to her Contributions (Stein, 2015, letter 142).

Ingarden probably found in Stein's treatises a more detailed description of the psychic structure generically outlined in On the Problem of Empathy, as well as a clear explanation of how the human psyche differs from consciousness and determines its lived experiences; terms such as "life-force" and "psychic causality" are particular significant in this respect. Additionally, he also found cause for reflection concerning the elements making up human subjectivity and about the need to admit a primal core of these elements, reminiscent of the traditional notion of soul.

Besides dovetailing with Ingarden's interest in the concept of person, Stein's reflections probably provided answers to questions that the Polish philosopher was asking himself in the same years, while beginning to question transcendental phenomenology in light of the controversy between idealism and realism. As we read in

28 It is not surprising that Ingarden, during a conference on Edith Stein's philosophy held in Krakow in 1968, remarked upon the importance and the philosophical value of her friend's early writings (Ingarden, 1999, 228). Her anthropology and her notion of soul are mentioned, too (250-253). 
his Letter to Husserl about the VI Investigation and Idealism (written in 1918): "From a comparative point of view, I see clearly the essential difference only in the contraposition between real external world and consciousness. On the contrary, as for the contraposition between psychic subject and pure consciousness, I do not see it clearly" (Ingarden, 1998, 6). We can conjecture that Stein's treatises published in 1922 helped him see more distinctly this conceptual pair, starting from the attempt-common to both thinkers-to investigate the ontological implications of the assumptions of Husserl's doctrine of transcendental idealism. After all, already in 1917 Stein revealed to Ingarden:

I think I now have a reasonably clear understanding of constitution - but outside the context of idealism. Prerequisites for an intuitive nature to constitute itself are: an absolutely existing physical nature and a subjectivity of a precise structure. So far, I have not gotten around to confessing this heresy to the Master. (Stein, 2015, letter 6) ${ }^{29}$

Since Ingarden aimed at cultivating a similar heresy by means of eidetic ontology, and since he was looking for a clearer view of this "subjectivity of a precise structure," he probably welcomed Stein's Contributions as a valuable input for his own research.

Several years later, in Chapter XVI of his main ontological work, the Polish thinker deepened the same topic with reference to the same aim to investigate the ontological foundations of idealism. When describing the formal relation between consciousness and soul, i.e., between the stream of consciousness and the psychic unity of the person, he was faced with the descriptive task he had already faced roughly around 1918 (as we have seen in his letter to Husserl) - a task that had oriented some of Stein's systematic analyses in the same years. It is therefore conceivable that these analyses kept on acting as reference models even during the writing of the section of Controversy dedicated to the person. The affinities between the two perspectives which emerged in the preceding sections of this article seem to corroborate this hypothesis.

\section{REFERENCES}

Ales Bello, A.(1993). Edith Stein und Hedwig Conrad-Martius: eine menschliche und intellektuelle Begegnung. Phänomenologische Forschungen (Studien zur Philosophie von Edith Stein: Internationales Edith-Stein-Symposion Eichstätt 1991), 26-27, 256-284.

29 These words are particularly relevant, considering that Stein transcribed the second volume of Husserl's Ideas, focused on phenomenological constitution. 
Ales Bello, A. (2001). The Study of the Soul Between Psychology and Phenomenology in Edith Stein. In The Philosophy of Edith Stein: The Eighteenth Annual Symposium of the Simon Silverman Phenomenology Center (3-17). Pittsburgh: Silverman Institute for Phenomenology at Duquesne University.

Avé-Lallemant, E. (1975a). Die Nachlässe der Münchener Phänomenologen in der Bayerischen Staatsbibliothek. Wiesbaden: Harrassowitz.

Avé-Lallemant, E. (1975b). Die Antithese Freiburg-München in der Geschichte der Phänomenologie. In H. Kuhn, E. Avé-Lallemant, \& R. Gladiator (Eds.), Die Münchener Phänomenologie. Vorträge des Internationalen Kongresses in München 13-18. April 1971 (19-38). Den Haag: Nijhoff.

Avé-Lallemant, E. (2003). Edith Stein und Hedwig Conrad-Martius. Begegnung in Leben und Werk. In B. Beckmann, \& H.-B. Gerl-Falkovitz (Eds.), E. Stein Themen-Bezüge-Dokumente (55-77). Würzburg: Königshausen \& Neumann.

Bertolini, S. (2019). Roman Ingarden: Phenomenology, Responsibility and the Ontological Foundations of Morality. Miscellanea Anthropologica et Sociologica, 20(1), 82-97.

Calcagno, A. (2019). Soul in Edith Stein (1891-1942). In Encyclopedia of Concise Concepts by Women Philosophers. Paderborn: Universitätsbibliothek. Retrieved from https://historyofwomenphilosophers.org/ecc/ hwps

Conrad-Martius, H. (1921). Metaphysische Gespräche. Halle: Niemeyer.

Hartmann, N. (1926). Ethik. Berlin: W. de Gruyter.

Husserl, E. (1952). Ideen zu einer reinen Phänomenologie und phänomenologischen Philosophie. Zweites Buch: Phänomenologische Untersuchungen zur Konstitution (Hua IV). Den Haag: Nijhoff.

Ingarden, R. (1925). Essentiale Fragen. Ein Beitrag zu dem Wesensproblem. Jahrbuch für Philosophie und phänomenologische Forschung, 7, 125-304.

Ingarden, R. (1964). Der Streit um die Existenz der Welt I. Tübingen: Max Niemeyer Verlag.

Ingarden, R. (1965). Der Streit um die Existenz der Welt II/2. Tübingen: Max Niemeyer Verlag.

Ingarden, R. (1968). Meine Erinnerungen an E. Husserl. In E. Husserl, Briefe an Roman Ingarden. Mit Erläuterungen und Erinnerungen an Husserl (106-135). Den Haag: Nijhoff.

Ingarden, R. (1970). Über die Verantwortung. Ihre ontischen Fundamente. Stuttgart: Philipp Reclam Jun.

Ingarden, R. (1974). Über die kausale Struktur der realen Welt. Tübingen: Max Niemeyer Verlag.

Ingarden, R. (1983). Man and Value. München: Philosophia Verlag.

Ingarden, R. (1994). Intuition und Intellekt bei Henri Bergson. In Roman Ingarden Gesammelte Werke Bd. 6 (Frühe Schriften zur Erkenntnistheorie) (1-199). Tübingen: Max Niemeyer Verlag.

Ingarden, R. (1998). Der Brief an Husserl über die VI. Untersuchung und den Idealismus (Ende Juli 1918). In Roman Ingarden Gesammelte Werke, Bd. 5 (Schriften zur Phänomenologie Edmund Husserls) (1-20). Tübingen: Max Niemeyer Verlag.

Ingarden, R. (1999). Die philosophischen Forschungen Edith Steins. In Roman Ingarden Gesammelte Werke, Bd. 3 (Schriften zur frühen Phänomenologie) (228-253).Tübingen: Max Niemeyer Verlag.

Ingarden, R. (2016). Controversy over the Existence of the World. Vol. II. Frankfurt a.M.: Peter Lang.

Knaup, M., \& Seubert, H. (Eds.). (2017). Edith Stein-Lexikon. Freiburg/Basel/Wien: Herder.

Makota, J. (1990). Roman Ingarden's Idea of Relatively Isolated Systems. Analecta Husserliana (Ingardeniana II: New Studies in the Philosophy of Roman Ingarden), vol. XXX, 211-223.

Pfänder, A. (1933). Die Seele des Menschen. Versuch einer verstehenden Psychologie. Halle: Max Niemeyer.

Scheler, M. (1980). Der Formalismus in der Ethik und die materiale Wertethik: neuer Versuch der Grundlegung eines ethischen Personalismus. In Gesammelte Werke II. Bern-München: Francke.

Stein, E. (2000). Philosophy of Psychology and the Humanities. Washington: ICS Publications Institute of Carmelite Studies. 
Stein, E. (2004). Einführung in die Philosophie. In Edith Stein Gesamtausgabe, Bd. 8. Freiburg/Basel/ Wien: Herder.

Stein, E. (2005). Potenz und Akt. Studien zu einer Philosophie des Seins. In Edith Stein Gesamtausgabe, $B d$. 10. Freiburg/Basel/Wien: Herder.

Stein, E. (2010a). Beiträge zur philosophischen Begründung der Psychologie und der Geisteswissenschaften. In Edith Stein Gesamtausgabe, Bd. 6. Freiburg/Basel/Wien: Herder.

Stein, E. (2010b). Zum Problem der Einfühlung. In Edith Stein Gesamtausgabe, Bd. 5. Freiburg/Basel/ Wien: Herder.

Stein, E. (2014). „Freiheit und Gnade“ und weitere Beiträge zu Phänomenologie und Ontologie (19171937). In Edith Stein Gesamtausgabe, Bd. 9. Freiburg/Basel/Wien: Herder.

Stein, E. (2015). Selbstbildnis in Briefen III: Briefe an Roman Ingarden. In Edith Stein Gesamtausgabe, $B d$. 4. Freiburg/Basel/Wien: Herder.

Walther, G. (1960). Zum anderen Ufer. Vom Atheismus zum Christentum. St. Goar: Otto Reichl Verlag. 